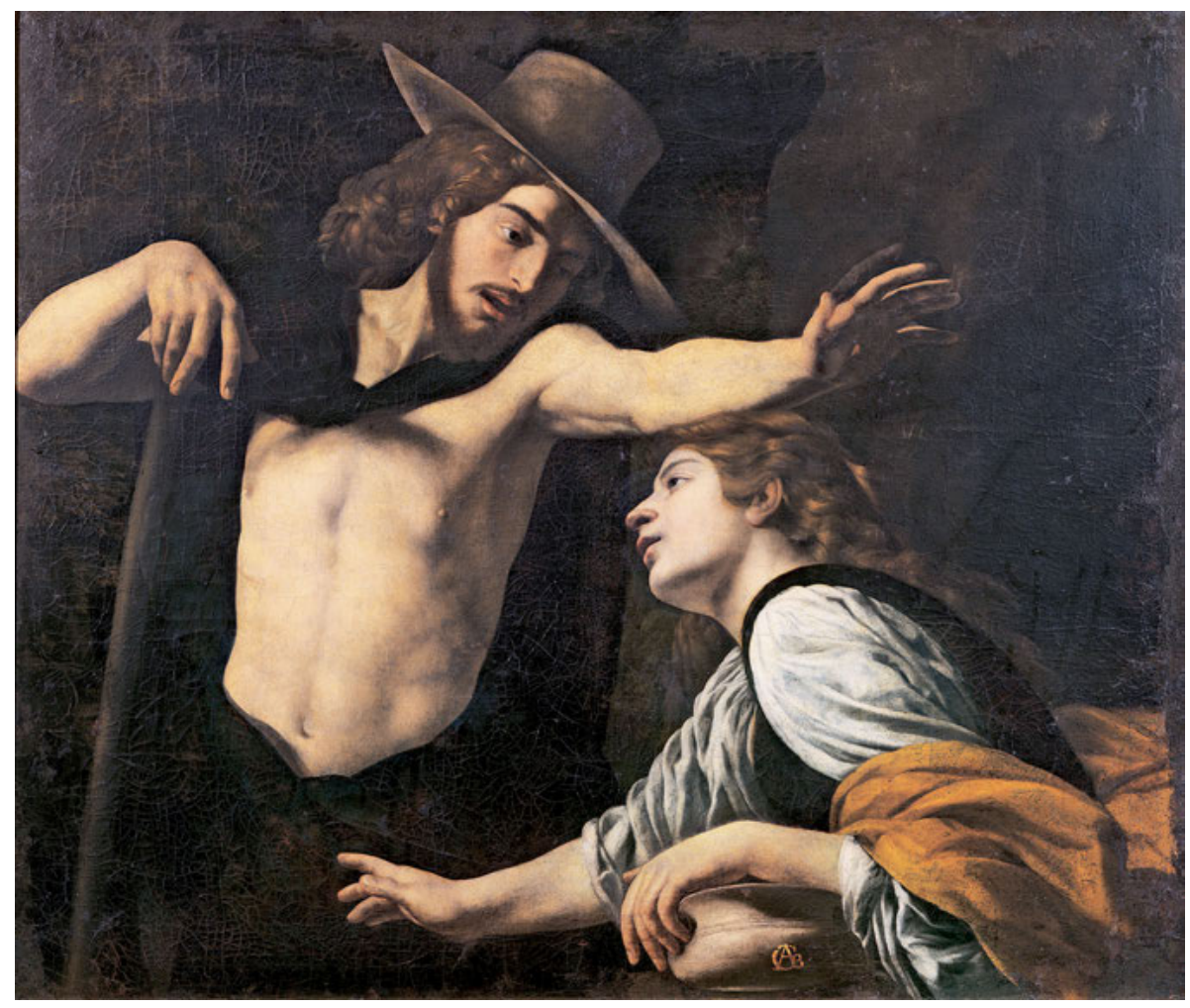

Fig. 9: Giovanni Battista Caracciolo (il Battistello), Noli me tangere, c. 1620, oil on canvas, 209x $131 \mathrm{~cm}$., Museo Civico, Palazzo Pretorio, Prato, Italy. Image Source: Heritage Images. 


\section{Noli me tangere: The Profaning Touch That Challenges Authority}

If scepticism can be broadly defined as a method as well as an attitude that criticises dogmatic assumptions and leads to a suspension of judgement, then a sceptical gesture can be conceived as a non-verbal way of expressing doubts or challenging authorities. The shift from a sceptical argument to a sceptical praxis is the passage from a linguistic definition to a bodily dimension in an anarchic shape. As is well known, anarchy etymologically means "the absence of arche," which has a double meaning: on the one hand, it means "origin," "beginning," and "principle of action," while on the other, it means "power," "command," and "authorities." Anarchy can be interpreted as more than a mere overthrowing of the arche; rather, it starts with a process of doubting and calling into question the political and social order. Shifting from an epistemological to a corporeal-political perspective, the sense of touch can be interpreted as a sceptical gesture towards authorities, since it deals with the body interpreted as a site of power. ${ }^{1}$

In this chapter, I will sketch some provisional notes on the provocative and "anarchic" aspects of the sense of touch, which, in its indeterminacy and reversibility, exceeds the borders of a univocal definition and therefore needs to be more measured and disciplined than the other senses. Touch allows the first immediate contact with otherness and represents an escape route from the integrity of the self, but at the same time, it shows the vulnerability of the body and the danger of contamina-

\footnotetext{
1 The body as a site of power is one of the most discussed issues in contemporary philosophical debate. This is not the place to offer an overview of this huge issue, but I would like to quote the incipit of Judith Butler's famous article in which she criticises Foucault's idea of the body. In my opinion, Butler's arguments may shed light on the complicated intrigue of this philosophical issue. See Judith Butler, "Foucault and the Paradox of Bodily Inscriptions," The Journal of Philosophy 86 (1989): 601: "The position that the body is constructed is one that is surely, if not immediately, associated with Michel Foucault. The body is a site where regimes of discourse and power inscribe themselves, a nodal point or nexus for relations of juridical and productive power. And, yet, to speak in this way invariably suggests that there is a body that is in some sense there, pregiven, existentially available to become the site of its own ostensible construction. What is it that circumscribes this site called 'the body'? How is this delimitation made, and who makes it? Which body qualifies as 'the' body? What establishes the 'the,' the existential status of this body? Does the existential body in its anonymous universality have a gender, an unspoken one? [...] To claim that 'the body is culturally constructed' is, on the one hand, to assert that whatever meanings or attributes the body acquires are in fact culturally constituted and variable. But not that the very construction of the sentence confounds the meaning of 'construction' itself. Is 'the body' ontologically distinct from the process of construction it undergoes? [...] In other words, 'the body' would not be constructed, strictly considered, but would be the occasion, the site, or the condition of a process of construction only externally related to the body that is its object."
} 
tion. In its uncanny and erotic proximity, the sense of touch has a privileged relationship with the symbolic representations of power in its political, religious, or social articulations. However, this bodily contact with authority is at the same time a risk and a challenge to the authority itself, which can be questioned by a profanatory touch.

This chapter will be structured in three sections. In the first, I will consider the reciprocity and the uncanniness of touch from a philosophical perspective. Far from being something that can be relegated to mere perception, the sense of touch is not a neutral process, but rather a medium of power relationships. In this regard, the skin also becomes a metaphorical deconstruction of borders between the I and the Other, as well as an epiphenomenon of social status. In the second section, starting from the episode of the Gospel of John and the famous injunction noli me tangere, I will consider the difference between two (gendered) desires to touch, that of St. Thomas and that of Mary Magdalene. In the third section, I will shed light on the gesture of touch as a challenge to authority and a kind of profanation of established rules. In order to do this, following Giorgio Agamben, I will consider the so-called museification of our society in which the prohibition of touch-and, therefore, of use-can be interpreted as a consequence of the extreme phase of capitalism.

\section{Sight and Touch/Pure and Impure}

As is commonly assumed, the Western tradition privileges sight as the sole mode of access to both beings and philosophical truth. ${ }^{2}$ Sight is the theoretical sense, ${ }^{3}$ while touch is the practical one; if the first is connected to thought and requires distance in order to detach the observer from the observed, the second, by contrast, needs proximity to unite the toucher and the touched. If seeing is believing, touching starts when seeing is not enough. It can be said that touch is driven by a primordial sceptical impulse.

Recently, many attempts have also been made to propose a philosophical history of touch in order to move from a metaphysics of sight to a materialism of touch. ${ }^{4}$ In particular, I am thinking here of Jean-Luc Nancy ${ }^{5}$ and Daniel Heller-Roazen, who, in

2 See Suzannah Biernoff, Sight and Embodiment in the Middle Ages (Basingstoke: Palgrave Macmillan, 2002), 66: "Most Indo-European terms for mental activity apparently derive from words for vision or the visible."

3 As is well known, theory is etymologically connected to sight: from Ancient Greek theōria ("contemplation, speculation, a looking at, things looked at"), theōreō ("I look at, view, consider, examine”), theōros ("spectator"), and thea (“a view”) + horaō ("I see, look").

4 At the beginning of her brilliant work on touch, Classen asks: "If a history could be written of touch, what would it embrace?” See Constance Classen, The Deepest Sense: A Cultural History of Touch (Urbana: University of Illinois Press, 2012), xi.

5 See Jean-Luc Nancy, Noli me tangere: essai sur la levée du corps (Paris: Bayard, 2003). 
the last chapter of his work The Inner Touch, leaves his readers with the question: "What would it mean for touch to be the root of thinking and for thinking, in turn, to be the most elevated form of a kind of touch?"6

How can we define touch? According to the Stanford Encyclopaedia of Philosophy,

the sense of touch is one of the central forms of perceptual experience. Thought to be the first sense to develop, touch occurs across the whole body using a variety of receptors in the skin. It often combines these signals with rich information made available by stretch receptors in the muscles and tendons as we actively move and explore the world. ${ }^{7}$

This scientific definition is partial, since it does not take into account the ambiguity of touch seen not only as a form of perception, but rather as a controversial philosophical and political threshold.

\section{The Reciprocity of Touch: The Open Skin}

Even if touch does not have a proper organ, since it is spread throughout the body, it can be said that the hand-the symbol of the homo faber-can be seen as the focus of touch, which is also the link between activities and thoughts, body and mind. As a peculiar property of human beings, the hand has been seen as a sign of human superiority. In the act of touching, activity and passivity are connected in the same process: it is possible to see without being seen and to hear without being heard, but not to touch without being touched. ${ }^{8}$ The hand, the body, and the skin are borders in a constant dialogue with exteriority and otherness. It can be said that this reciprocity of touch may play a pivotal role from both a philosophical and a political perspective. For instance, in his essay entitled "Haut" (Skin), the philosopher Vilém Flusser described a dynamic representation of the skin as a fictive limit in which the external and internal worlds communicate with each other. Much more than a surface that constitutes the body, the skin is a place of exchange between the I and the world: "The skin lies between the future and the past, between freedom and work (Werk), whereby these skin horizons overlap one another."9

6 Daniel Heller-Roazen, The Inner Touch: Archaeology of a Sensation (New York: Zone Books, 2007), 285.

7 Matthew Fulkerson, “Touch,” in The Stanford Encyclopedia of Philosophy (Spring 2016 Edition), ed. Edward N. Zalta, https://plato.stanford.edu/archives/spr2016/entries/touch/.

8 See Edmund Husserl, Ideas Pertaining to a Pure Phenomenology and to a Phenomenological Philosophy. Second Book: Studies in the Phenomenology of Constitution, trans. Richard Rojcewicz and André Schuwer (Dordrecht: Kluwer Academic Publishers, 1989), 152-59; Maurice Merleau-Ponty, Signes (Paris: Gallimard, 1960).

9 Vilém Flusser, "Haut," Flusser Studies 2 (2006): 2, accessed 01/07/2020, http://www.flusserstudies.net/sites/www.flusserstudies.net/files/media/attachments/flusser-haut02.pdf. 
This exchange with the external is a process of subjectivity. The reciprocity of the skin and the sense of touch allow this openness to the world and to the Other. Therefore, there is an intrigue of subject and object, as the contemporary philosopher Michel Serres underlines: "I caress your skin, I kiss your mouth. Who, I? Who, you? When I touch my hand with my lips, I feel the soul like a ball passing from one side to the other of the point of contact, the soul quickens when faced with such unpredictability." 10 Following his argumentation, we can say that touch works as a kind of medium or, to be more specific, as a mixture, since it has no specific object and tends towards fluidity:

The skin is a variety of contingency: in it, through it, with it, the world and my body touch each other, the feeling and the felt, it defines their common edge. Contingency means common tangency: in it, the world and the body intersect and caress each other. I do not wish to call the place in which I live a medium, I prefer to say that things mingle with each other and that I am no exception to that, I mix with the world which mixes with me. Skin intervenes between several things in the world and makes them mingle. ${ }^{11}$

The map that touch provides is a mobile one in which the contours are smooth and flexible. It creates a form of commonality, which is a kind of mixture where each surface touches another in an unavoidable proximity.

\section{The Uncanniness of Touch: A Matter of Life or Death}

However, this proximity is related to a dangerous uncanniness. In his brilliant work On Touching-Jean-Luc Nancy, Derrida stated that the sense of touch is unclear, since it is unapparent, obscure, secret, and nocturnal. In fact, it has many aporetic elements: though the other senses have their proper sensible objects (colour for vision, sound for the sense of hearing, and flavour for taste), touch comprises several different qualities. While according to the common understanding of this sense, I can only touch some extended things (res extensa), it does not follow that every extension is touchable. The act of touching is always a threshold, in which a limit, a surface, a border is touched:

It is touching that touches on the limit, its own "proper-improper" limit, that is to say on the untouchable whose border it touches. To touch on the limit is not, for contact, just any experi-

10 Michel Serres, The Five Senses: A Philosophy of Mingled Bodies (I), trans. Margaret Sankey and Peter Cowley (New York: Continuum, 2008), 26.

11 Serres, 80. 
ence among others or a particular figure: one never touches except by touching a limit at the limit. $^{12}$

Aristotle-according to Derrida, the greatest thinker to ever discuss touch-stated in his De anima that without touch, there would be no other senses and animals could not exist. Touch has a unique place in his discourse on living beings, since the sense of touch alone is necessary for the survival of animals and men:

It is evident, then, that of necessity animals deprived of this sense alone will die. For nothing having this can fail to be an animal, nor does what is an animal need any sense other than this. ${ }^{13}$

One can say that anthropopoiesis-the self-building process of human beings-is deeply connected to touch. However, since it deals with survival, it needs to be measured: animals would die without touch, but they would also die with a surplus of it. Touch should imply both contact and distance. Aristotle insisted that both the tangible and the intangible are the objects of touch. ${ }^{14}$ There is an a priori untouchability since touching, as a question of life and death, concerns our Da-sein, our relations with the world. This ambiguity is the haunting of touch, which has something that exceeds itself, a surplus of touch that is untouchable. Since touching deals with its own limits, it is deeply related to transgression, sacrilege, and profanation. This "untouchability" 15 can be defined as a limit or a prohibition, which constitutes a dynamic of power in itself and its manifestations through religion and social relationships.

12 Jacques Derrida, On Touching-Jean-Luc Nancy, trans. Christine Irizarry (Stanford: Stanford University Press, 2005), 297.

13 Aristotle, De anima, translated with and introduction and commentary by C. Shields, (Oxford: Clarendon, 2016), 435b4-7.

14 Aristotle, 424a.

15 Concerning the notion of the "untouchable," see Derrida, On Touching-Jean-Luc Nancy, 330 n. 17: "Since the untouchable here is neither mind nor consciousness but, verily, body proper and in the flesh, one has indeed to think the logic of an untouchable remaining right at, right on the touchable, if one may say so still. This touchable-untouchable [...] is not someone, nor is it what certain cultures term an 'untouchable.' But this 'untouchable' with its prohibition against being touched could not be announced, named, and identified in this way except inasmuch as-let me stress again-there is some touchable-untouchable in general, before any religion, cult, or prohibition. Any vow of abstinence-hence avowing both the touchable and the untouchable-experiments with the touchable as untouchable, in a betrayal that is originary and therefore unforgivable, or imprescriptible, as is said of crimes against humanity in France today: outside the statute of limitations." 


\section{Touch as Medium of the Divine}

Touch can be interpreted from another perspective as a metaphor for the transmission of spiritual and religious power. ${ }^{16}$ The touch of God is an all-powerful manifestation of his omnipotence and his supreme power over nature. Since touch is not possible without direct contact, it can be interpreted as the medium par excellence in which the divine passes through the human condition. Touch can bring direct contact with holiness and the body of Christ is touchable, but-despite this carnal representation-it cannot be possessed, even in the Eucharistic display of his body (hoc est corpus meum).

The aesthetic dimension of soteriology involves several theological issues. In the Old Testament, through his divine touch, God purifies people from sin and manifests his divine truth. Furthermore, touching is also connected to the regulation of laws and to the ceremonial cleanness, which prohibits contact with unclean things, such as certain foods and corpses. ${ }^{17}$ The New Testament reformulates the theme of touch through the sensible figure of Jesus. All of the Gospels-which can be taken as a "general haptics," 18 to quote Derrida-present the body of Christ not as a body of revelation, but as a suffering body: "as a body touching as much as touched, as flesh that is touched-touching." 19

In the Bible, there is always a physical proximity to the body of Jesus, who lets himself be touched and heals with touch; through his hands, Jesus performs miracles and gives tangible signs of his supernatural power. He multiplies food with his hands, cures people of sickness, and restores them to life. His healing powers are shown through direct contact and his omnipotence passes through a physical manifestation.

The bodily aspect is also preserved in everyday practices: crossing oneself, giving the kiss of peace, placing one's hands together in prayer. On the one hand, the performance of these ritual gestures is a devotional touch; on the other, it is a way of disciplining bodies. In this context, it is worth mentioning the role of touch in the particular use of the body made by mystics. For instance, Bernard of Clairvaux considered touch as the perfect metaphor for faith-“Christ urges us: "touch me with the

16 See David Morgan, “The Senses in Religion," in A Cultural History of the Senses. Volume 5: In the Age of Empire, ed. Constance Classen (London: Bloomsbury, 2005), 95: "Seeing and tasting were powerful ways of seeking out religious authenticity, but so were touching and smelling. Touch was understood to be the ancient medium for the transmission of spiritual authority in the catholic tradition, beginning with the apostles' bodily embrace with Jesus, the apostolic practice of laying on hands by church elders, and descending over time through the consecrating blessing of a bishop's hand on a new priest."

17 See Lev 11:15 and Deut 14.

18 Derrida, On Touching-Jean-Luc Nancy, 100.

19 Derrida, 100. 
hand of faith, the finger of desire, the embrace of love"'20-while in the visionary mystical experience, the sense of touch played a crucial role: in the Ancrene Wisse (Guide for Anchoresses), a monastic rule written in the early thirteenth century, there is an invitation to touch Jesus in a visionary trance: "Touch him with as much love as you would a man." ${ }^{21}$ In this regard, this sublimated touch is assumed to be a bridge to another (divine or sensual) sphere, through which the body is purified and transformed. However, on the other hand, since mystics and ascetics practise strict bodily discipline-including sexual abstinence, deprivation, self-castigation, and self-inflicted pain-the (carnal) surplus of the sense of touch has to be rigidly regulated.

\section{Mary Magdalene and Thomas: Two Metaphors of Touch}

Within this religious framework, I would like to discuss a particular episode from the Gospels, without dwelling on the issue of the saving touch of divine grace. "Touch me not!” is Jesus's admonition to Mary Magdalene after his resurrection, because he becomes momentarily untouchable. ${ }^{22}$ This famous locution is a hapax legomenon

20 Quoted in Classen, The Deepest Sense, 30.

21 See Classen, 89.

22 See John 20:11-20, 24-29: "Now Mary stood outside the tomb crying. As she wept, she bent over to look into the tomb and saw two angels in white, seated where Jesus' body had been, one at the head and the other at the foot. They asked her, 'Woman, why are you crying?' 'They have taken my Lord away,' she said, 'and I don't know where they have put him.' At this, she turned around and saw Jesus standing there, but she did not realize that it was Jesus. He asked her, 'Woman, why are you crying? Who is it you are looking for?' Thinking he was the gardener, she said, 'Sir, if you have carried him away, tell me where you have put him, and I will get him.' Jesus said to her, 'Mary.' She turned toward him and cried out in Aramaic, 'Rabboni!' (which means 'Teacher'). Jesus said, 'Noli me tangere [touch me not], for I have not ascended to the Father. Go instead to my brothers and tell them, "I am ascending to my Father and your Father, to my God and your God."' Mary Magdalene went to the disciples with the news: 'I have seen the Lord!' And she told them that he had said these things to her. Jesus Appears to His Disciples. On the evening of that first day of the week, when the disciples were together, with the doors locked for fear of the Jewish leaders, Jesus came and stood among them and said, 'Peace be with you!' After he said this, he showed them his hands and side. The disciples were overjoyed when they saw the Lord. [...] Jesus Appears to Thomas. Now Thomas (also known as Didymus), one of the Twelve, was not with the disciples when Jesus came. So, the other disciples told him, 'We have seen the Lord!' But he said to them, 'Unless I see the nail marks in his hands and put my finger where the nails were, and put my hand into his side, I will not believe.' A week later his disciples were in the house again, and Thomas was with them. Though the doors were locked, Jesus came and stood among them and said, 'Peace be with you!' Then he said to Thomas, 'Put your finger here; see my hands. Reach out your hand and put it into my side. Stop doubting and believe.'Thomas said to him, 'My Lord and my God!' Then, Jesus told him, 'Because you have seen me, you have believed; blessed are those who have not seen and yet have believed."” 
in the Gospels. "Noli me tangere [touch me not], for I have not ascended to the Father. Go instead to my brothers and tell them, I am ascending to my Father and your Father, to my God and your God." On that evening, Jesus appears to his disciples, but Thomas Didymus is not among them and doubts their testimony: "Unless I see the nail marks in his hands and put my finger where the nails were, and put my hand into his side, I will not believe." Eight days later, Jesus says to Thomas: "Put your finger here; see my hands. Reach out your hand and put it into my side. Stop doubting and believe." Thomas then recognises his lord and God, but Jesus says to him: "Because you have seen me, you have believed; blessed are those who have not seen and yet have believed."

One might say that here, there are two different desires to touch at stake: the woman touches because she recognises Jesus and believes in him, while the man wants to touch Jesus's body because he does not believe, or better, because he needs proof in order to believe. Mary Magdalene cannot touch; Thomas touches, but his touch aims at a confirmation. The first act is due to an overabundance of belief, the second to a lack of faith. Both gestures-that of Mary Magdalene attempting to lay her hands on Jesus and that of Thomas, who needs to put a finger in the wound -involve touching, but the former deals with an acknowledgement, while the latter deals with doubt. ${ }^{23}$ It can be said that these two paradigmatic cases show the ambiguity of touch seen, on the one hand, as an act driven by desire and, on the other, as a proof of certainty. The flesh wants a proof of existence that exceeds mere faith, which is why it is a sin. However, believing without touching is in line with the whole of the Western philosophical tradition. This thread links Plato to the Christian belief, where the truth may be touched by giving up corporeal understanding.

These two episodes from the Gospel of John related to touch exerted a huge influence in the history of ideas. Intellectuals speculated on these two passages, in particular concerning the nature of the body of Christ and the reason why Mary Magdalene could not touch Christ's body while Thomas was invited to do so. ${ }^{24}$ According to the medieval interpretation, Mary's touch was too carnal, since she wanted to touch the body of Christ as a mortal man. ${ }^{25}$ The scandalous touch of the woman was a touch of desire, while Thomas's request-due to his masculine nature-was a "superior” kind of desire connected to a need for knowledge that was much more similar to

23 See the brilliant work by Glenn W. Most, Doubting Thomas (Cambridge, MA: Harvard University Press, 2005), ix: “The figure of Doubting Thomas gives us an excellent opportunity to put our finger upon central questions of faith and doubt, scepticism and persuasion, along two dimensions through a variety of media.”

24 See Marjorie O'Rourke Boyle, Senses of Touch: Human Dignity and Deformity from Michelangelo to Calvin (Leiden: Brill, 1998); Caroline Walker Bynum, The Resurrection of the Body in Western Christianity: 200-1336 (New York: Columbia University Press, 1995); Classen, The Deepest Sense, 27-46; Most, Doubting Thomas.

25 See Most, 39: “Evidently Mary’s joy at discovering his beloved body once more in front of her is so great that, with a deeply human and immediately understandable gesture, her first instinct is to touch it lovingly." 
sight. ${ }^{26}$ It can be said that there is a kind of gendered connotation of senses, which is connected to a particular hierarchy: the lower senses-touch, taste, and smell-are usually linked to the lower (feminine) sex, while the higher senses of sight and hearing are associated with the higher (masculine) sex. If the feminine stereotypes relate to an intimate sensual and bodily experience, the distance of sight and hearing is associated with a (supposedly) masculine rationality. The woman's touch may be seen as a challenge to the rational masculine discipline of society. ${ }^{27}$ The sensuality of Mary Magdalene has always been connected with carnal desire, which remains unsatisfied, while Thomas-who touched the body of Christ-has been interpreted as a "scientific" enquirer. The prohibition that engenders desire opposes the rational satisfaction of objective evidence.

\section{From Noli me tangere to Noli me credere}

The desire to touch does not only deal with sacred bodies, but also with sacred objects. ${ }^{28}$ This is the case for saintly relics, the cults of which were astonishingly popular in the Middle Ages. Relics could usually be touched-or better kissed-either di-

26 See Most, 72: "The idea of touching Jesus' wounded body seems to exert far too strong a fascination upon most readers when they encounter it for them to be able later simply to forget it, or dismiss it, or explain it away-especially since what is involved is touching it not with a loving caress, like Mary Magdalene, but with a sceptical thrust (though translators often say that Thomas wants to 'place' his hand in Jesus' side, in fact the Greek verb used by John is much stronger and means basically to 'throw' or 'hurl')."

27 It is not by chance that there are two paradigmatic examples: the prostitute and the witch. These female bodies were exempt from the ordinary women's work on which the social order was based. The seductive and dangerous touch of the woman was exemplified in the aberrant touch that could bewitch ordinary men and enter into contact with demons. In both cases, the sense of touch plays an important role, since it is a symbol of what must be put on the edges of society.

28 There is also an interesting connection between touch and religious books; in fact, since the written texts could be interpreted as an impersonal medium, the human body-through speech and other senses-was commonly assumed to be a tactile and "embodied" one. It was no accident that not everyone was permitted to touch books in the Middle Ages and early modern period. See Classen, The Deepest Sense, 18-19: "One medieval scribe wrote of the toll writing took on his body: 'A man who knows not how to write may think this is no great feat. But only try to do it yourself and you will learn how arduous is the writer's task. It dims your eyes, makes your back ache, and knits your chest and belly together-it is a terrible ordeal for the whole body.' Reading, while perhaps not such an ordeal as writing, was no mere matter of gliding one's eyes over a page. Medieval readers had to deal with poor illumination, cramped script, uncomfortable seating, and temperature extremes. [...] In the semi-oral society of the Middle Ages, embodied memory might well be thought superior to, or at least an important adjunct to, written records." It is worth noting that this episode of Mary Magdalene had a huge influence on the imagination of thinkers and writers; for instance, the Victorian novelist Marie Corelli in her work "Electric Creed," published in 1886, depicted Jesus as an electric body who could not touch Mary Magdalene because of his dangerously high voltage after his resurrection. 
rectly or through a shrine, but in any case, there were rules to protect them from insolent and inappropriate treatment:

To understand the particular appeal the remains of the saints had in the Middle Ages one has to think of the saint's body not as a lifeless corpse, but as a supernatural force (called virtus) manifested in a personalized material form-a supernatural force that had the power to grant one good health, good fortune, and a good end-all through the medium of touch. ${ }^{29}$

Touching the relics was seen as the only effective way to transfer their holy power. However, many attempts were made to control this tactile access to the sacred and tactile proximity was substituted with visual distance. This was not only due to the Reformation; even during the Middle Ages, plagues and the fear of contagion led to a kind of tactophobia that played a crucial role in the substitution of touch with sight.

It is worth noting that the issue of the reliability or authenticity of relics engendered a sceptical attitude towards the power of touch to transfer the holy power contained in the bones, clothes, or hair of a saint. There was an interesting passage from noli me tangere to noli me credere,$^{30}$ a slipping from the prohibition to touch to the prohibition to believe in the absence of empirical evidence of the body of God, from Mary Magdalene to Thomas. Religion became more and more intangible, while its sensible and bodily aspects had to be sublimated into an intangible holy sphere.

\section{Touch as a Sceptical Challenge to Authority}

This dichotomy between touchable and untouchable can be interpreted as the heart of darkness of every community. The practices of touching are always indicators of specific power relationships in which there is an oscillation between the imperative and the prohibition to touch. Both commands have to do with the regulation of touch by political or religious authorities. Purity and impurity and cleanliness and uncleanliness are philosophical, political, and religious concepts. The meaning of the Latin sacro was "set something aside" for the service of God or for the use of a divinity, while something profanus was something that could not be used in a religious sense, since it was dirty and contaminated.

Starting from the ancient period, touch was an important means of differentiating between social groups, since some sensory stereotypes also shaped the difference

29 Classen, The Deepest Sense, 40.

30 See Classen, 151: "When the sixteenth-century Franciscan François du Moulin visited the shrine of Mary Magdalene and was shown her skull with the supposed imprint of Jesus's fingers he noted that, while monks called the relic 'Noli me tangere,' 'Do not touch me' (in reference to Jesus's injunction to Mary Magdalene), he called it 'Noli me credere'-'Do not believe me.”' 
between the elite and the masses, the rich and the poor. The skin was a kind of epiphenomenon of social position; imperfections, scars, and tattoos were a physical reminder of a lowly status. Therefore, the shape and use of the body corresponded to a specific idea of social order.

Hearing a voice or smelling a perfume is completely different from touching clothes or bodies, which is a much more invasive action. Since the act of touching -as pleasure or pain-can violate the (holy) inviolability of the body, it has to be regulated and ordered by a rigid discipline; in fact, it is not by chance that the regulation of touch-since it represents a challenge to the social order-involves religion and politics; moreover, it is not by chance that criminal behaviours are very often connected to the unlawful touching of property and persons.

In the communal sharing that was the foundation of society during the Middle Ages, shared bodily practices were at the heart of everyday life. The dirty connotations of touch even assumed a pivotal role in the modern and contemporary age; for instance, Canetti speaks of the "repugnance of being touched [...] in a busy street." 31 The transformation of the city into conglomerates of strangers, an anonymity combined with the sense of privacy and private property, has made the tactile experience-especially touching another body-a controversial way of communicating between people that has to be disciplined.

Contemporary Western society is a result of a deep "hygienic process" in which the common forms of social touching, as they existed before, have been banned. The root of this impulse of hygienisation may be traced back to the fear and risk of contamination, which reminds us of the old plagues such as leprosy or the Black Death. Lepers were the untouchable par excellence and they were obliged to wear special clothing and to carry a bell in order to warn others. The figure of the leper is paradigmatic because he is a person who cannot touch or be touched; therefore, he is cut off from everyday sociality, such as communal eating using the hands, sitting around the fire, and sleeping. Due to this process of hygienisation, ${ }^{32}$ we are living in a permanent neutralisation of bodily relationships and the tactile impulse has to be controlled: "Look, but don't touch!"

\section{Do Not Touch: The Museification of Society}

As a clear example of this prohibition, we can examine the case of museums and then the so-called museification of our society. It is worth noting that the prohibition of touching objects is rather a new trend; in fact, in the seventeenth and eighteenth centuries, it was possible to touch artworks in order to have an intimate connection

31 Elias Canetti, Crowds and Power, trans. Carol Stewart (London: Victor Gollancz, 1962), 15. 32 See Christopher E. Forth and Ivan Crozier, Body Parts: Critical Explorations in Corporeality (Lanham: Lexington Books, 2005). 
with and specific knowledge of the museum objects. In early museums-most of which were private collections-touching the collections was commonplace, since it was a popular and meaningful way of interacting with the artworks, which were supposed to be handled. Tactile interaction was not only a sign of hospitality, but also a real encounter and a medium of knowledge through which the form and content of the artefacts could be truly discovered in order to correct mistakes or misconceptions of the sight: "palpando experiri potest." 33

When museums became more open to the public in the nineteenth century, they turned themselves into treasure hoards and-also due to the urgency of conservation -into spaces of prohibition. The public access to museums transformed them into places whose special features had to be justified through prohibitions. Among these prohibitions, the sense of touch had to be controlled and disciplined more often than the other senses.

However, learning not to touch in modern museums was a gradual process due to various phenomena. The elimination of touch implied that the collections had become inviolable through the specific techniques of museum display, and this element completely changed the visitors' attitude. Tactile experience gave way to visual contemplation, the bodily and sensual pleasure of art was gradually replaced with strict discipline, and the faculty of vision became predominant in the modern museum. The hands-off rule of museums is due to their transformation into public places where it is not possible to control the "vulgar" touch of the masses-and also the working class-who have access to them. In the new museum, artworks, artefacts, and sculpture became tools of a new disciplinary regime.

This untouchability is matched with the hygienisation of our contemporary society. It can be said that authority exercises its power through this injunction and that noli me tangere has nowadays become the prohibition par excellence. It deals with abuse, impurity, consumption, damage, offence, or simply with usage, pleasure, and enjoyment. There is an everyday use of this prohibition in which power, consumption, and usage are interwoven. This conjunction raises many questions: What does this untouchable represent? What does this register of warning mean? Why is it forbidden to touch? What is the grammar of this gesture? Could we interpret the act of touching as a radical calling into question of authority in general? Does touch involve a radical (a)political form of resistance? Is touch a temporary suspension of the apparatus of power?

In order to interpret the grammar of this phenomenon, I will briefly use Giorgio Agamben's idea of profanation as an act of resistance and a process whereby what has been given up in the sacred sphere is restored for another profane and human use. ${ }^{34}$

33 See Constance Classen, "Museum Manners: The Sensory Life of the Early Museum," Journal of Social History 40 (2007): 901.

34 Giorgio Agamben, "In Praise of Profanation," in Agamben, Profanations, trans. Jeff Fort (New York: Zone Books, 2007), 73-92. 


\section{The Profanation of Touch}

If we-along with Agamben-consider museification not as a physical space or place, but rather as a "pure form of separation" and a phenomenon which "designates the exhibition of an impossibility of using, of dwelling, of experiencing," 35 then the connection between (the prohibition of) touch and (the prohibition of) profanation becomes clear.

In his famous essay entitled In Praise of Profanation, Agamben stated that "if 'to consecrate' (sacrare) was the term that indicated the removal of things from the sphere of human law, 'to profane' meant, conversely, to return them to the free use of man." 36 This meaning of profanation is deeply connected to the sphere of use and is antithetical to religion that is not understood as religare (to unify), but as relegere, "which indicates the stance of scrupulousness and attention that must be adopted in relations with the gods." 37 Separating between two different spheres is the essence of religion, while "to profane means to open the possibility of a special form of negligence, which ignore separation or, rather, puts it to a particular use." 38 The apparatus which regulates the passage from the profane to the sacred is the sacrifice that works as a ritual caesura. In this regard, Agamben mentions contagione as the simplest form of profanation:

Thus, one of the simplest forms of profanation occurs through contact (contagione) during the same sacrifice that effects and regulates the passage of the victim from the human to the divine sphere. One part of the victim (the entrails, or exta: the liver, heart, gallbladder, lungs) is reserved for the gods, while the rest can be consumed by men. The participants in the rite need only touch these organs for them to become profane and edible. There is a profane contagion, a touch that disenchants and returns to use what the sacred had separated and petrified. ${ }^{39}$

The idea of a profanation through contact is deeply connected to an ancestral idea of power. It can be said that contagione through the act of touching is a political operation, since it acts as a deactivation of religious or political power and a restitution to common use. To continue Walter Benjamin's idea of capitalism as religion, Agamben stated that present-day capitalism has pushed the religious tendency of separating between the sacred and the profane to extremes: "In its extreme form, the capitalist religion realizes the pure form of separation, to the point that there is nothing left to separate."40 According to Agamben, the capitalistic sphere of consumption engenders an absolute consecration, which is the same as a total profanation, meaning

\footnotetext{
35 Agamben, 84.

36 Agamben, 73.

37 Agamben, 74-75.

38 Agamben, 75.

39 Agamben, 74.

40 Agamben, 81.
} 
that nothing is profanable: "The capitalist religion in its extreme phase aims at creating something absolutely unprofanable." 41 This happens because in the objects of consumption, use coincides with abuse, with a destruction of the objects themselves: "Consumption, which necessarily destroys the thing, is nothing but the impossibility or the negation of use, which presupposes that the substance of the thing remains intact." 42

Since capitalism is the apotheosis of consumption, real use is not permitted. The prohibition of touch can be interpreted as an injunction, which manifests this impossibility of use. The loss of use is nothing but the loss of profaning, and therefore, the act of touch is a dangerous act of resistance, because it represents a profanation, seen as a restoration of the real human use that is nowadays forbidden. The prohibition of touching displays a capitalistic perspective according to which there is only the domain of exclusively (divine) use, where everything is sacred and hence off-limits for personal use. Since the omni-sacralisation of capitalism impedes use, touch has nowadays become a dangerous and sceptical challenge to authority. It can be said that at the core of this contrast, there is a pure and sacral capitalistic consumption opposing the dirty gesture of touch, the dogmatism of order facing the scepticism of the body.

Beyond a mere epistemological conception or scientific definition, touch can be interpreted as a way of bridging the gap between man and the Other, but on the other hand, it provokes a radical and uncanny proximity. This Apollonian-Dionysian duality emerges if one considers touch from another perspective; namely, as a medium of religious holiness, an epiphenomenon of social status as well as an act of profanation. In these frameworks, which I have tried to outline in this essay, touch fluctuates from an interdiction to a desire, from a prohibition to a resistance. If bodies are fields, in which power manifests itself and authorities exercise their control, touch can be seen as a possible provisional interruption of this dynamic and a suspension of the rules through bodily praxis. Due to this haptic epoche of authorities, the dirty, profane, and anarchic sense of touch becomes the sceptical gesture that radically calls into question the established order and sacred power.

\section{Bibliography}

Agamben, Giorgio. Profanations. Translated by Jeff Fort. New York: Zone Books, 2007.

Aristotle. De anima. Translated with and introduction and commentary by C. Shields. Oxford: Clarendon, 2016.

Aristotle. De partibus animalium. Translated by William Ogle under the editorship of J.A. Smith and W.D. Ross. Oxford: Clarendon Press, 1911.

41 Agamben, 82.

42 Agamben, 82. 
Biernoff, Suzannah. Sight and Embodiment in the Middle Ages. Basingstoke: Palgrave Macmillan, 2002.

Butler, Judith. "Foucault and the Paradox of Bodily Inscriptions." The Journal of Philosophy 86 (1989): 601-7.

Canetti, Elias. Crowds and Power. Translated by Carol Stewart. London: Victor Gollancz, 1962.

Classen, Constance. The Deepest Sense: A Cultural History of Touch. Urbana: University of Illinois Press, 2012.

Classen, Constance. "Museum Manners: The Sensory Life of the Early Museum." Journal of Social History 40 (2007): 895-914.

Derrida, Jacques. On Touching-Jean-Luc Nancy. Translated by Christine Irizarry. Stanford: Stanford University Press, 2005.

Flusser, Vilém. "Haut." Flusser Studies 2 (2006). Accessed 01/07/2020. http://www.flusserstudies.net/sites/www.flusserstudies.net/files/media/attachments/flusser-haut02.pdf.

Forth, Christopher E., and Ivan Crozier. Body Parts: Critical Explorations in Corporeality. Lanham: Lexington Books, 2005.

Fulkerson, Matthew. "Touch.” In The Stanford Encyclopedia of Philosophy (Spring 2016 Edition), edited by Edward N. Zalta, https://plato.stanford.edu/archives/spr2016/entries/touch/. Accessed 1.7.2020.

Heller-Roazen, Daniel. The Inner Touch: Archaeology of a Sensation. New York: Zone Books, 2007. Husserl, Edmund. Ideas Pertaining to a Pure Phenomenology and to a Phenomenological Philosophy. Second Book: Studies in the Phenomenology of Constitution. Translated by Richard Rojcewicz and André Schuwer. Dordrecht: Kluwer Academic Publishers, 1989.

Merleau-Ponty, Maurice. Signes. Paris: Gallimard, 1960.

Morgan, David. "The Senses in Religion: Migrations of Sacred and Sensory Values." In A Cultural History of the Senses. Volume 5: In the Age of Empire, edited by Constance Classen, 89-111. London: Bloomsbury, 2005.

Most, Glenn W. Doubting Thomas. Cambridge, MA: Harvard University Press, 2005.

Nancy, Jean-Luc. Noli me tangere: essai sur la levée du corps. Paris: Bayard, 2003.

O'Rourke Boyle, Marjorie. Senses of Touch: Human Dignity and Deformity from Michelangelo to Calvin. Leiden: Brill, 1998.

Serres, Michel. The Five Senses: A Philosophy of Mingled Bodies (I). Translated by Margaret Sankey and Peter Cowley. New York: Continuum, 2008.

Walker Bynum, Caroline. The Resurrection of the Body in Western Christianity, 200-1336. New York: Columbia University Press, 1995. 